\title{
PENINGKATAN POTENSI WISATA DESA WAGINOPO DENGAN MENGOPTIMALKAN SUMBER DAYA MELALUI PROGRAM EKONOMI KREATIF
}

\author{
Syamsul Hadi ${ }^{1,{ }^{*}} \mid$ Wibowo $^{1}$ | Joko Triyono ${ }^{1}$ | La Ode Rujunia ${ }^{2}$ | La Ode Nasrianto ${ }^{3}$ \\ ${ }^{1}$ Teknik Mesin, Fakultas Teknik, Universitas Sebelas Maret \\ ${ }^{2}$ Waginopo, Wangiwangi, Wakatobi, Sulawesi Tenggara \\ зMaleko, Wangiwangi, Wakatobi, Sulawesi Tenggara
}

\begin{abstract}
Abstrak
Desa Waginopo merupakan salah satu desa di Kecamatan Wangi-wangi, Kabupaten Wakatobi, Provinsi Sulawesi Tenggara. Desa Waginopo merupakan salah satu dari pemekaran desa Tindoi Raya yang terletak di kawasan puncak Pulau Wanci, Kabupaten Wakatobi. Desa Waginopo tergolong dalam desa berkembang setelah mengalami kemajuan dari yang sebelumnya berstatus sebagai desa tertinggal. Desa Waginopo memiliki kekayaan berupa sumber daya alam yang amat melimpah. Kegiatan Kuliah Kerja Nyata (KKN) UNS Wakatobi bertujuan untuk mengoptimalkan kekayaan sumber daya alam Desa Waginopo untuk dapat dikelola dengan baik dan meningkatkan sumber daya manusia desa agar dapat mengelola kekayaan alam dengan optimal dengan melaksanakan 20 program berupa 10 program kerja utama dan 10 program kerja penunjang. Program kerja yang dilaksanakan terfokus kepada bidang pariwisata yang memiliki kegiatan berupa Peta Wisata, Toliamba Information Centre, Mural Toliamba, Sosialisasi Inovasi Homestay, dan Explore Wakatobi. Program utama tersebut kemudian didukung program bidang ekonomi kreatif dengan program kerja berupa Made in Toliamba, sosialisasi pemasaran, packaging and labeling, vertikultur serta souvenir made by Toliamba, program bidang lingkungan yang memiliki kegiatan survey gua, penyuluhan pertanian, tadah dan penyaring air hujan serta Waginopo bersih berseri, dan program bidang kemasyarakatan yang memiliki program antara lain Rumah Kreasi, PHBS, Who am $i$, What is Your name dan Plural is me. Program-program yang disusun dapat terlaksana dengan baik berkat dukungan dari pemerintah daerah maupun pemerintah desa serta antusiasme masyarakat dalam berkontribusi untuk program yang dilaksanakan.
\end{abstract}

Kata kunci : Pariwisata, pendidikan, kesehatan, sosial, KKN, Waginopo, Wakatobi

\section{Pendahuluan}

Definisi pariwisata adalah sebagai sebuah perjalanan bersifat sementara dari suatu tempat ke tempat lain baik dilakukan secara perorangan maupun kelompok sebagai usaha untuk mencari keseimbangan atau keserasian dan kebahagiaan dengan lingkungan hidup dalam dimensi sosial, budaya, alam dan ilmu (Spilane,1987). Kesegaran baik fisik maupun psikis agar dapat berprestasi lagi diharapkan dicapai kembali setelah melakukan aktivitas pariwisata yang didukung berbagai upaya pengembangan pariwisata termasuk juga pengusahaan obyek daya tarik wisata serta usaha-usaha yang terkait di bidang tersebut (Fandeli, 1995). Usaha tersebut melibatkan industri-industri klasik seperti kerajinan tangan dan cinderamata, serta usaha-usaha penginapan, restoran dan transportasi sehingga menjadikan pariwisata sebagai sebuah sektor yang kompleks (Pendit, 1990), dan pengembangan pariwisata memiliki tiga fungsi yaitu untuk menggalakkan ekonomi, memelihara kepribadian bangsa dan kelestarian fungsi dan mutu lingkungan hidup serta, memupuk rasa cinta tanah air dan bangsa (Joyosuharto, 1995). Dengan pentingnya dan kompleksnya permasalahan berkaitan dengan pariwisata maka diperlukan berbagai strategi pengembangan daerah wisata (Sefira dkk., 2013; Meiwany dkk., 2018; Soebagyo, 2012; dan Febrianti dkk., 2014).

Kuliah Kerja Nyata (KKN) merupakan program dari universitas untuk memberikan kesempatan mahasiswa untuk meningkatkan soft skillnya (Sunardhi, 2018) dengan hidup bersama masyarakat sehingga dapat membantu dan mendampingi masyarakat untuk menggali potensi sumber daya manusia

\footnotetext{
* Penulis Korespondensi. Email: syamsulhadi@ft.uns.ac.id
} 
dan alam yang ada sehingga dapat mengatasi permasalahan yang ada dan meningkatkan taraf hidup ke arah yang lebih baik (UNS, 2013). Sebagai sebuah lokasi KKN, Desa Waginopo adalah desa yang terletak di Kecamatan Wangi-wangi, Kabupaten Wakatobi, Provinsi Sulawesi Tenggara. Desa Waginopo terdiri dari 2 dusun, yaitu Dusun Toliamba Jaya dan DusunWaginopo. Desa Waginopo terletak di daerah perbukitan atau wilayah puncak dari Pulau Wangi-wangi. Desa Waginopo merupakan bagian dari pemekaran Desa Tindoi Raya. Letak Desa Waginopo bagian barat berbatasan dengan Desa Pada Raya Makmur, dan bagian timur berbatasan dengan Desa Posalu. Jarak dari Kantor Kecamatan Wangi-wangi menuju Desa Waginopo menempuh waktu kurang lebih 30 menit. Dengan pariwisata sebagai leading sector dalam meraup devisa negara, $\mathrm{KKN}$ di daerah lokasi wisata merupakan sesuatu hal yang menarik dikaji (Syamsul dkk., 2019). Pun juga dengan posisi letak desa Waginopo di pulau Wakatobi sebagai salah satu tujuan utama pariwisata di Indonesia dan adanya lokasi wisata yaitu Taman Puncak Toliamba dan potensinya yang ada di desa Waginopo, pengembangan pariwisata di desa Waginopo merupakan bahasan yang menarik untuk dijadikan tema pengabdian kepada masyarakat. Permasalahan yang ada adalah bagaimana mengarahkan segenap potensi yang ada di masyarakat untuk mendukung pengembangan pariwisata di desa tersebut.

\section{Metode Pelaksanaan}

Dari berbagai permasalahan yang ada di Kelurahan Waginopo, dilakukan pendataan awal kondisi yang ada di masyarakat dan kemudian dilakukan beberapa kegiatan pada periode KKN UNS Januari-Februari 2020 untuk membantu masyarakat mengatasi permasalahan yang ada dengan metode survey, sosialisasi, pendampingan, kerja bersama, motivasi, penyuluhan dan monitoring. Metode yang dilakukan tersebut disesuaikan dengan potensi alam dan potensi manusia di Desa Waginopo.

Khalayak sasaran kegiatan adalah aparat desa, kelompok tani, ibu-ibu PKK, anak anak, kelompok wanita tani, dan masyarakat desa Waginopo yang mempunyai motivasi untuk pengembangan diri. Tahapan pelaksanaan KKN tersebut dapat diuraikan dalam satu tema besar tentang pengembangan pariwisata yang terdiri dari beberapa kegiatan yaitu Desain Peta Wisata, Explore Wakatobi, Toliamba Information Center, Mural Toliamba, Sosialisasi Inovasi Homestay, Eksplore Wakatobi, Made in Toliamba, Packaging and Labeling, Souvenir Made By Toliamba, Sosialisasi Pemasaran, Waginopo Bersih Berseri, Rumah Kreasi. Sedangkan kegiatan oendukung pariwisata meliputi Vertikultur, Survey Gua, Penyuluhan Pertanian, Tadah air Hujan, Penyaringan Air Hujan, Plural Is Me, What Is Your Name, Who am I, dan PHBS.

\section{Hasil dan Pembahasan \\ Pendataan Kondisi Awal}

Keadaan wilayah Desa Waginopo berupa pegunungan/perbukitan dengan hamparan laut Wakatobi. Penduduk Desa Waginopo memiliki mata pencaharian yang beragam. Sebagian besar bermatapencaharian di bidang perkebunan/pertanian. Selebihnya masyarakat Desa Waginopo bermatapencaharian sebagai nelayan, pengrajin, hingga pegawai negeri sipil seperti disampaikan di Tabel 1. Komoditas tanaman yang banyak ditanam di Desa Waginopo antara lain kelapa, kolang-kaling, umbi-umbian, pisang, hingga buah pala dan kenari. Sebagian besar lahan di Desa Waginopo adalah lahan tidur. Selebihnya lahan di Desa Waginopo adalah pemukiman warga, dan lahan pertanian. Dengan struktur masyarakat seperti ini sarana pendidikan yang ada hanya terdiri dari 1 PAUD, 1 Sekolah Dasar, 1 SMP dan 1 SMA.

Permasalahan di bidang pendidikan meliputi sarana dan prasarana sekolah yang kurang memadai, contohnya belum adanya mushola dan kamar madi/jamban yang layak, selain itu kesadaran masyarakat untuk menyekolahkan anaknya di jenjang selanjutnya masih minim. Hal tersebut dapat dilihat dari sedikitnya siswa yang kurang memiliki motivasi untuk melanjutkan ke pendidikan selanjutnya. Sebagian warga hanya menyekolahkan anaknya sampai sekolah dasar atau sekolah menengah pertama, dikarenakan akses jalan yang tidak memadai dan di samping itu juga didasari keinginan anak sendiri untuk langsung bekerja. Disamping sarana sekolah Desa Waginopo juga memiliki prasarana dan sarana yang cukup memadai, antara lain: Gedung Sekolah Menengah Pertama, Gedung Sekolah Dasar, 
Gedung Aula Serbaguna Desa, Gedung Balai Desa, Gedung Pendidikan Anak Usia Dini, Badan Usaha Milik Desa, Sarana Ibadah (Masjid), Penampungan air desa. Akan tetapi sarana kesehatan desa masih belum ada. Jarak pusat kesehatan masyarakat dari Desa Waginopo yang cukup jauh menjadi evaluasi pembangunan sarana kesehatan desa kedepannya.

Tabel 1. Mata Pencaharian warga Waginopo dan Toliamba Jaya

\begin{tabular}{|l|l|c|c|c|c|c|c|}
\hline & Nama Dusun & Petani & Nelayan & Pedagang & Pengrajin/Pertukangan & PNS & Lainnya \\
\hline 01 & Waginopo & 172 & 4 & 5 & 5 & 3 & 0 \\
\hline 02 & Toliamba Jaya & 215 & 7 & 20 & 10 & 15 & 5 \\
\hline & Jumlah & 387 & 11 & 25 & 15 & 18 & 5 \\
\hline
\end{tabular}

Kabupaten Wakatobi merupakan daerah yang memiliki penduduk dengan hampir seluruhnya beragama Islam. Tempat/fasilitas ibadah yang dimiliki berupa Masjid Kanatul 'Ain yang terletak di Dusun Toliamba Jaya. Kegiatan di Masjid Kanatul 'Ain Desa Waginopo selain menjadi fasilitas ibadah sholat juga untuk kegiatan kajian, Ta'lim, Yasinan rutin setiap malam jum'at, taman baca Alquran, hingga kegiatan ramadhan. Kawasan masjid dilengkapi dengan perpustakaan atau taman baca yang dapat diakses dan menjadi fasilitas bagi masyarakat mulai dari anak-anak hingga remaja dan dewasa. Dengan banyaknya kegiatan keagamaan ini masyarakat sangat menjunjung tinggi gotong royong dan toleransi antar warga. Desa Waginopo memiliki kegiatan rutin berupa festival budaya hingga kegiatan keagamaan lainnya. Masyarakat Desa Waginopo memiliki budaya gotong royong untuk setiap hajatan yang diadakan oleh setiap warga seperti aqiqah, sunat, hingga perkawinan. Masyarakat Desa Waginopo sangat menjunjung tinggi adat istiadat dan kebudayaan. Terdapat sanggar tari yang terletak di Dusun Toliamba Jaya yang digunakan sebagai tempat belajar menari dan melestarikan tarian khas daerah.

Kesehatan dan kebersihan lingkungan merupakan masalah-masalah yang penting untuk diperhatikan di kawasan pedesaan. Desa Waginopo sudah menjadi desa yang cukup memperhatikan keadaan kebersihan lingkungan. Desa Waginopo sudah memiliki tempat pembungan akhir (TPA). Selain itu Desa Waginopo telah menerapkan program buang sampah pada tempatnya dengan mendistribusikan tempat sampah di masing-masing kepala keluarga. Kondisi ini ditunjukkan dengan keadaan kebersihan lingkungan yang cukup baik meski warga belum memiliki kesadaran akan kesehatan lingkungan yang cukup baik. Hal tersebut ditandai dengan belum adanya sarana kesehatan masyarakat di desa. Desa Waginopo belum memiliki posyandu untuk pelayanan terpadu kesehatan masyarakat desa. Selain itu Desa Waginopo masih belum memiliki Puskesmas. Jarak Pusat Kesehatan Masyarakat terdekat dari Desa Waginopo masih terbilang cukup jauh.

\section{Hasil dan Pembahasan}

Program Explore Wakatobi ini bertujuan untuk mencari tempat yang memiliki potensi wisata tetapi belum dimanfaatkan oleh masyarakat maupun tempat yang belum ditemukan. Dengan adanya kegiatan ini diharapkan menjadi sarana memperkenalkan tempat wisata dan juga sebagai penyadaran untuk pemerintah serta masyarakat desa bahwa masih banyak tempat yang dapat dijadikan tempat wisata alternatif. Faktor yang mendukung untuk berjalannya program ini yaitu adanya dukungan dan fasilitas akomodasi yang memadai dari desa serta warga yang menemani selama berjalannya program ini. Sedangkan faktor yang menghambat berjalannya program ini yaitu kurangnya jangkauan sinyal yang berakibat pada susahnya memperkenalkan secara online melalui situs google maps. Hasil yang dicapai dari berjalannya program ini yaitu pemasaran tempat wisata melalui video dokumenter selama program berlangsung. Kegiatan yang belum terlaksana yaitu menginput lokasi yang ditemukan ke dalam google maps yang diharapkan bisa dilakukan dalam program KKN berikutnya.

Desain Peta Wisata merupakan kegiatan untuk pemetaan tempat wisata yang bisa dikembanngkan oleh warga desa Waginopo. Salah satu tempat wisata alternatif di Waginopo yang bernama Taman Puncak Toliamba. Sayangnya, banyak fasilitas pendukung wisata yang belum ada di tempat tersebut. Berangkat dari keresahan tersebut maka dilakukan pemetaan di Toliamba secara manual, dari data tersebut diolah menjadi desain peta menggunakan aplikasi Coreldraw dan dilakukan pencetakan serta pemasangan 
sehingga harapannya dapat membantu mempermudah wisatawan untuk mencari setiap spot yang ada di Toliamba. Kemudian juga ada kegiatan pembuatan Toliamba Information Center yang merupakan sarana wisata berupa papan informasi wisata disamping peta wisata. Toliamba Information Centre memuat informasi mengenai tempat wisata puncak Toliamba. Papan informasi ini memuat mengenai bagian-bagian apa saja yang ada di tempat wisata puncak Toliamba. Hasil kedua kegiatan tersebut sudah tercapai dengan pemasangan peta pada 2 titik seperti di sampaikan di Gambar 1, tindaklanjut yang diharap adanya perawatan serta pembaharuan setiap adanya pembangunan. Faktor yang mendukung dari berjalannya program Desain Peta Wisata yaitu adanya kebutuhan lingkungan untuk mempermudah wisatawan. Sedangkan faktor yang menghambat jalannya program ini yaitu minimnya pengawasan dari warga/dinas mengenai keberlanjutan peta tersebut dan minimnya pengawasan dari warga/dinas mengenai keberlanjutan peta tersebut.

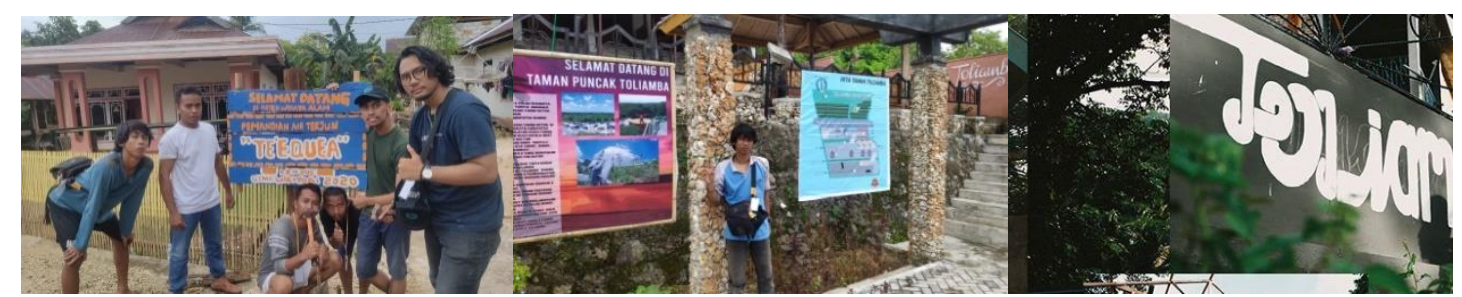

Gambar 1. Peta Wisata, Toliamba Information Centre, dan Mural Toliamba

Kegiatan berikutnya yang dilakukan adalah Sosialisasi Inovasi Homestay. Sosialisasi inovasi homestay yang dilaksanakan diikuti dengan program kerja Made in Toliamba serta penyuluhan pengemasan dan pelabelan. Kegiatan ini dimaksudkan untuk memberi kesadaran adanya potensi homestay yang dapat dikembangkan pemilik rumah di desa Waginopo. Meskipun desa Waginopo mempunyai masalah air yang cukup menyulitkan masyarakat maka diharapkan kegiatan ini dapat menjadi contoh yang dapat membantu masyarakat desa untuk merawat, mengembangkan rumahnya masing-masing dengan materi standarisasi homestay yang sudah diberikan. Upaya membantu dengan memberikan pengetahuan standarisasi homestay dilanjutkan dengan kegiatan cara pemasaran homestay terutama melalui situs ecommerce seperti Traveloka dan Agoda. Antusiasme masyarakat desa Waginopo terhadap homestay masih tergolong kurang. Masyarakat Waginopo belum sepenuhnya sadar terhadap usaha homestay yang memiliki prospek bisnis yang cukup menguntungkan. Faktor yang mendukung pengembangan homestay adalah peminat homestay pada pulau Wanci mempunyai banyak peminat dan desa Waginopo berupa daerah yang mendukung dengan adanya homestay dikarenakan adanya potensi wisata.

Hasil yang dapat ditinggalkan adalah pengetahuan homestay lebih lanjut serta cara memasarkan homestay tersebut terutama dengan fasilitas internet yang berupa e-commerce. Tindak lanjutnya untuk inovasi homestay adalah pendaftaran properti homestay pada situs e-commerce serta membuat pernak pernik berupa dekorasi interior homestay yang mempunyai tujuan untuk memberi kesan kearifan local pada homestay tersebut. Kurangnya partisipasi masyarakat untuk datang di kegiatan sosialisasi. Harapannya pada awalnya kegiatan ini diikuti oleh bapak ibu rumah tangga yang sudah mempunyai homestay dan yang memiliki ketertarikan untuk mengembangkan homestay. Masyarakat yang datang pada sore hari mayoritas adalah ibu-ibu rumah tangga yang berupa audience program kerja Made in Toliamba. Faktor mencari kerja dengan merantau ke pulau lain membuat peserta yang hadir adalah ibuibu rumah tangga. Sedang Made In Toliamba dilaksanakan di Gode-gode Wa Ina Toliamba dimaksudkan untuk memberikan inovasi olahan makanan dan memanfaatkan komoditas hasil pertanian untuk nilai jual yang lebih tinggi. Dengan cara mengolah pisang menjadi keripik dan nugget pisang dan menginovasi nasi bambu menjadi nasi bakar dengan berbagai isian. Kegiatan Made in Toliamba ini bisa berjalan dengan lancar dengan adanya kerjasama antara mahasiswa KKN dengan kelompok kuliner desa Waginopo dan adanya respon baik oleh ibu-ibu yang menjadikan banyak tanya jawab.

Hasil yang dicapai dari pelaksanaan program ini yaitu adanya inovasi baru dari hasil komoditas yang ada sehingga bisa dikembangkan dan bisa diperjualbelikan sehingga memberi masukan kepada masyarakat Desa Waginopo. Lebih lanjut dilakukan Sosialisasi optimalisasi pemasaran dilaksanakan 
dengan kegiatan Souvenir Made By Toliamba juga di Gode - Gode Wa Ina. Kegiatan ini dihadiri oleh pemuda dan pemudi dari Desa Waginopo. Kegiatan ini dimaksudkan agar pemuda dan pemudi desa Wagiopo mendapatkan wawasan baru mengenai inovasi souenir yang khas dari desa Waginopo. kegiatan ini dilaksanakan dengan harapan dapat meningkatkan perekonomian desa Waginopo dengan cara yang lebih modern dan dapat menjadi ilmu pengetahuan tambahan untuk masyarakat khususnya pemuda dan pemudi desa. Faktor yang mendukung jalannya acara yaitu antusiasme yang tinggi dari para pemuda dan pemudi desa untuk mengetahui info info yang diberikan. Pemuda dan pemudi desa mendapatkan wawasan baru mengenai inovasi souvenir sebagai cinderamata khas. Setelah itu dilakukan sosialisasi optimalisasi pemasaran yang dihadiri oleh pemuda dan pemudi dari Desa Waginopo. Kegiatan ini dimaksudkan agar pemuda dan pemudi desa Wagiopo mendapatkan informasi mengenai berbagai platform e-commerce maupun social media yag dapat digunakan untuk mengoptimalisasikan pemasaran dan penjualan produk produk souvenir yang khas dari desa Waginopo.

Kegiatan ini dilaksanakan dengan harapan dapat meningkatkan perekonomian desa Waginopo dengan cara yang lebih modern dan dapat menjadi ilmu pengetahuan tambahan untuk masyarakat khususnya pemuda dan pemudi desa. Faktor yang mendukung jalannya acara yaitu antusiasme yang tinggi dari para pemuda dan pemudi desa untuk mengetahui info info yang diberikan. Mereka juga banyak bertanya mengenai materi optimalisasi pemasaran ini. Sedangkan faktor yang menjadi penghambat dalam acara ini yaitu, di awal memulai materi peserta yang hadir masih kurang kondusif dikarenakan mereka masih antusias untuk membuat souvenir. Namun, hal itu tidak berjalan lama, beberapa menit berselang peserta mulai kondusif lagi. Dan dengan bantuan tim KKN yang dapat mengondisikan peserta. Hasil yang dicapai yaitu pemuda dan pemudi desa mengerti strategi yang harus dijalankan untuk memasarkan dan menjual produk souvenir agar lebih banyak konsumen yang membeli dan agar lebih banyak lagi dikenal oleh orang di luar Wakatobi.

Usaha lain yang dilakukan adalah pengadaan dan pendidikan pembuatan mural dalam kegiatan Mural Toliamba. Mural merupakan kegiatan penanaman nilai seni kepada masyarakat Wangi-wangi guna menunjang desa Waginopo untuk menjadi desa wisata. Dengan adanya mural ini di berbagai lokasi wisata dapat lebih indah dan pengunjung tidak hanya ke 1 lokasi wisata saja. Mural di laksanakan yang berlokasi sebelah mesjid untuk menarik minat anak-anak di desa membaca Alqur'an dan buku pelajaran dengan hiasan gambar. Mural juga di laksanakan pada lokasi Kelompok Sadar Wisata (Pokdarwis) yang bertujuan untuk mengajak para pemuda di desa untuk menambah kreatifitas dengan melakukan kegiatan mural. Kegiatan mural ini tidak hanya untuk lokasi wisata tetapi juga di laksanakan yang berlokasi di perpustakaan sekolah SMP negeri 3 wangi-wangi yang bertujuan untuk menumbuhkan rasa nyaman di perpustakaan dan mengembangkan ide kreatif tentang kesenian. Program mural dapat berjalan dengan lancar di karenakan dengan kerja sama yang baik oleh mahasiswa kkn, pemuda dan masyarakat yang merespon positif.sedangkan penghambat dalam program ini adalah ide tentang seni lukis / mural masih sedikit yang mengetahui nya. Hasil yang dicapai dalam program ini adalah meningkatnya pengetahuan tentang kesenian yang sangat bermanfaat di berbagai bidang di lingkungan masyarakat. Sebelum dilaksanakannya program ini, kami melakukan pengecekan lokasi yang di jadikan mural dan bersosialisasi dengan masyarakat. Masyarakat sangat setuju dengan lokasi yang sudah di tentukan untuk di mural dan mendapatkan respon yang baik. Program ini mendapatkan keterbukaan dari pihak sekolah dan masyarakat dengan pengadaan program mural ini.

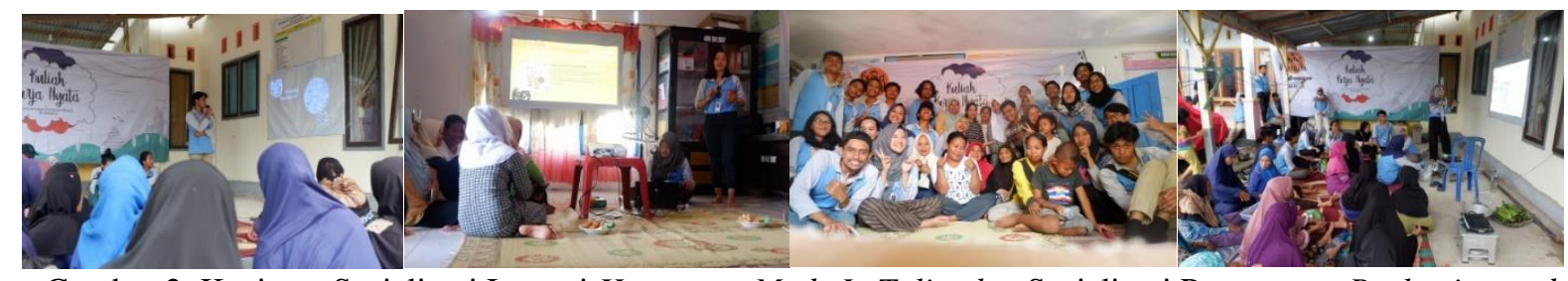

Gambar 2. Kegiatan Sosialisasi Inovasi Homestay, Made In Toliamba, Sosialisasi Pemasaran, Packaging and Labeling. 
Upaya lain untuk meningkatkan kemampuan ekonomi pariwisata warga adalah kegiatan sosialisasi Packaging and Labelling. Kegiatan sosialisasi Packaging and Labelling yang ditujukan untuk 30 warga perwakilan dari kelompok kuliner desa dimaksudkan untuk memberikan informasi untuk memberikan pemahaman kepada warga akan pentingnya packaging atau pengemasaan dari sebuah produk dalam rangka meningkatkan daya jual suatu produk dan pencantuman label informasi pada produk untuk memberikan keterangan pada konsumen mengenai produk tersebut sehingga konsumen merasa aman ketika membeli produk tersebut. Program kegiatan Packaging and Labelling ini dapat berjalan dengan lancar karena adanya kerjasama antara TIM KKN UNS dengan perangkat desa yang turut berpartisipasi dalam penyebaran informasi dan pengerahan masa dari kelompok kuliner Desa sehingga acara dapat terpublikasi dengan baik dan warga antusias untuk datang. Hambatan dari pelaksanaan program kegiatan ini adalah kurang tersedianya bahan Packaging produk yang bervariasi sehingga harus membeli secara online, sedangkan mayoritas peserta belum mengerti bagaimana alur pembelian barang secara online ditambah dengan ongkos kirim yang mahal. Hasil yang dicapai dari pelaksanaan program kegiatan ini seperti di sampaikan di Gambar 2 adalah peserta dapat mengerti pentingnya Packaging sebuah sproduk untuk menaikan harga jual dari produk tersebut dan sadar akan pentingnya pencantuman label pada produk untuk memberikan informasi yang komunikatif.

Proker yang berjudul "Who Am I" bergerak pada bidang sosial pendidikan. Program ini mentargetkan pada siswa sekolah tingkat Sekolah Dasar dan Sekolah Menengah Pertama dan bertujuan untuk memicu semangat siswa dalam menggapai cita-cita atau impian yang diinginkannya. Cita-cita atau impian menjadi penting karena hal tersebut dapat menjadi suatu pegangan atau tujuan dan arahan bagi siswa sehingga tidak buta dalam mengarahkan tujuan hidup atau studinya. Proker ini dilakukan dengan cara pendekatan pada tiap-tiap kelas yang dilakukan oleh kakak-kakak dari KKN. Kemudian dijelaskan kepada siswa tentang Cita-cita seperti yang sudah persiapkan sebelumnya. Dilakukan pula penggambaran tentang cita-cita siswa pada pohon cita-cita yang selanjutnya akan ditempelkan di tiaptiap kelas dengan tujuan agar dapat selalu dilihat dan menjadi penyemangat bagi siswa-siswi. Dari program kerja Who Am I yang sudah dijalankan, kami berharap bahwa siswa-siswi yang telah mendapatkan materi dari program tersebut dapat semakin yakin terhadap cita-citanya, atau setidaknya dapat membantu siswa-siswi untuk menemukan cita-citanya. Dengan adanya cita-cita diharapkan menumbuhkan semangat belajar agar dapat meraih apa yang diinginkan mereka. Setelah program selesai dilaksanakan sangat besar harapan bahwa nantinya terdapat program lanjutan yang sesuai dan mendukung program Who Am I yang mengangkat persoalan cita-cita, dengan tujuan agar siswa-siswi selalu diingingatkan tentang tujuan nya di masa depan sehingga meningkatkan semangat hidup dan belajar. Selain itu untuk menunjang pariwisata juga dilakukan kegiatan What's Your Name yang berisi permainan bahasa Inggris antar kelompok di masing-masing kelas dengan jumlah total siswa kurang lebih 120 siswa yang terbagi menjadi 6 kelas.

Kegiatan ini dimaksudkan untuk mempersiapkan generasi muda Wakatobi, terkhusus di Desa Waginopo untuk bisa berbahasa Inggris, mengingat Wakatobi merupakan salah satu 10 destinasi prioritas dan tentunya banyak turis mancanegara yang berkunjung ke Wakatobi. Sehingga nantinya para generasi muda ini dapat berkomunikasi dengan turis mancanegara dan bisa memajukan pariwisata Wakatobi, khususnya Desa Waginopo. Program kegiatan What's Your Name dapat berjalan dengan lancar karena adanya kerjasama antara tim mahasiswa KKN dengan perangkat sekolah SMPN 3 Wangiwangi yang juga sangat mendukung kegiatan ini. Hal tersebut terbukti dengan adanya himbauan dari pihak sekolah kepada para siswa pada sehari sebelumnya untuk membawa kamus pada hari kegiatan berlangsung. Hambatan dari pelaksanaan program kegiatan ini adalah cuaca yang tidak mendukung di hari kegiatan berlangsung, sehingga sebagian siswa datang terlambat dan menimbulkan jadwal kegiatan yang mundur $1 \mathrm{jam}$. Hasil yang dicapai dari pelaksanaan program kegiatan ini adalah para siswa menjadi lebih familiar terhadap bahasa Inggris dan mengetahui beberapa pertanyaan yang bisa ditanyakan kepada turis jika mereka bertemu turis mancanegara. Selain itu juga dilakukan kegiatan Rumah Kreasi yang berisi peningkatan daya kreasi dan softskil anak anak di desa Waginopo. Kegiatan ini dilaksanakan 3 kali seminggu yaitu setiap hari Senin, Kamis dan Jumat di masjid. Pada hari Senin fokus pada kegiatan pendalaman agama meliputi membaca dan belajar Al-Qur'an, setelah itu anak laki- 
laki fokus pada belajar adzan dan perempuan mendengar ceramah dari kakak KKN. Pada hari Kamis, kegiatan membaca dan belajar Al-Qur'an dan juga memberi kesempatan kepada semua anak-anak untuk menyelesaikan PR dan tugas dari sekolah. Pada hari Jumat, kegiatan membaca dan belajar Al-Qur'an, dan melatih kreativitas anak-anak dengan membuat prakarya dari kertas origami. Di setiap pertemuan, selalu diberikan kegiatan pengenalan yel-yel dan ice breaking yang dapat meningkatkan fokus anakanak dalam belajar dan dapat meningkatkan semangat mereka untuk datang ke Rumah Kreasi (Masjid).

Kegiatan ini juga bertujuan untuk meningkatkan pengetahuan anak-anak di bidang spiritual dan dapat membentuk karakter bermoral. Faktor pendukung kegiatan ini adalah karena adanya kerjasama antara tim mahasiswa KKN dengan kelompok TPA Al-Hidayah desa Waginopo. Selain itu antusiasme yang sangat tinggi dari anak-anak di desa tersebut untuk datang ke Rumah Kreasi sehingga meningkatkan semangat tim pengajar KKN. Hambatan dari pelaksanaan program ini adalah cuaca yang tidak menentu seperti hujan deras yang membuat anak-anak tidak berangkat ke Rumah Kreasi. Hasil yang dicapai ari pelaksanaan program ini adalah anak-anak mampu membaca dan belajar Al-Qur'an dengan pedoman dan aturan membaca sesuai dengan Tarjwi dan secara Tartil, meningkatkan minat membaca dan kreativitas anak-anak, dan dapat meningkatkan minat anak-anak untuk selalu belajar khususnya bidang spiritual. Partisipasi dan dukungan masyarakat serta perangkat desa sangat baik yaitu dengan selalu mengantarkan anak-anak desa Waginopo untuk datang ke Rumah Kreasi. Peran dari anak-anak dan guru TPA yang senantiasa aktif dalam kegiatan-kegiatan yang kami lakukan untuk menghidupkan rumah kreasi. Plural-is-me merupakan kegiatan penanaman nilai toleransi sejak dini kepada siswa-siswi SMP 3 Wangi-wangi guna menunjang visi-misi desa Waginopo untuk menjadi desa wisata pilihan. Dengan budaya toleransi yang tercipta sejak dini, diharapkan pelancong akan merasa aman dan nyaman berwisata di Waginopo.

Kegiatan ini berlangsung dengan mekanisme kegiatan yang digunakan adalah 20 mahasiswa KKN dibagi menjadi 6 kelompok untuk bertanggungjawab atas kelasnya masing-masing dengan satu orang berperan sebagai koordinator lapangan. Adapun bentuk kegiatan yang dilakukan di dalam kelas adalah permainan interaktif dan pengajaran dengan metode jigsaw. Program Plural-is-me dapat berjalan dengan lancar karena adanya kerjasama yang baik antara tim KKN UNS, jajaran pengurus sekolah dan siswa-siswi SMP 3 Wangi-wangi. Sedangkan hambatan dari program ini adalah adanya perubahan jadwal yang dilakukan oleh pihak sekolah yang sedang beradaptasi dengan system full-day school. Hasil yang dalam program ini adalah meningkatnya pengetahuan dan kesadaran siswa-siswi SMP 3 Wangi-wangi akan nilai-nilai keberagaman budaya, pluralism, dan toleransi. Selain itu, mereka pun semakin tertarik untuk mengetahui lebih banyak tentang daerah lain di luar Wakatobi. Sebelum diselenggarakannya program ini, kami melakukan asesmen dasar seputar nilai toleransi yang sudah ada di desa Waginopo. Masyarakat sangat terbuka dalam menceritakan nilai toleransi tersebut dengan detail, hal ini sangat memudahkan pelaksanaan Plural-is-me. Selain itu, keterbukaan dan keluwesan pihak sekolah dalam mengatur jadwal pengadaan program juga sangat baik.

Penyuluhan Pertanian Ruang Vertikultur berisi kegiatan pengenalan vertikultur dan cara pembuatannya kepada warga, dengan contoh alat berupa vertikultur pipa paralon. Kegiatan ini dihadiri 30 orang warga Desa Waginopo yang berprofesi sebagai petani. Kegiatan ini dimaksudkan untuk memberikan wawasan di bidang pertanian dan memberikan solusi alternatif pertanian apabila kesulitan akses air di kebun. Kegiatan Penyuluhan Ruang Vertikultur ini dapat berjalan lancar karena adanya kerjasama antara tim mahasiswa KKN dengan perangkat desa Waginopo, juga adanya antusiasme masyarakat terhadap inovasi di bidang Pertanian yang kami kenalkan. Hambatan dari program kerja ini yaitu mundurnya waktu dimulainya acara dikarenakan pada jam tersebut warga masih banyak yang berkebun dan mengurusi urusan rumah tangga, sehingga waktu mundur 1 jam dari yang dijadwalkan. Hasil yang dicapai dari pelaksanaan program kerja ini yaitu adanya antusiasme dan kemauan masyarakat untuk membuat vertikultur di rumahnya masing-masing dan adanya rencana penganggaran dana desa untuk mengadakan program pembuatan vertikultur di rumah-rumah warga, sebagai tindak lanjut program kegiatan kami. 


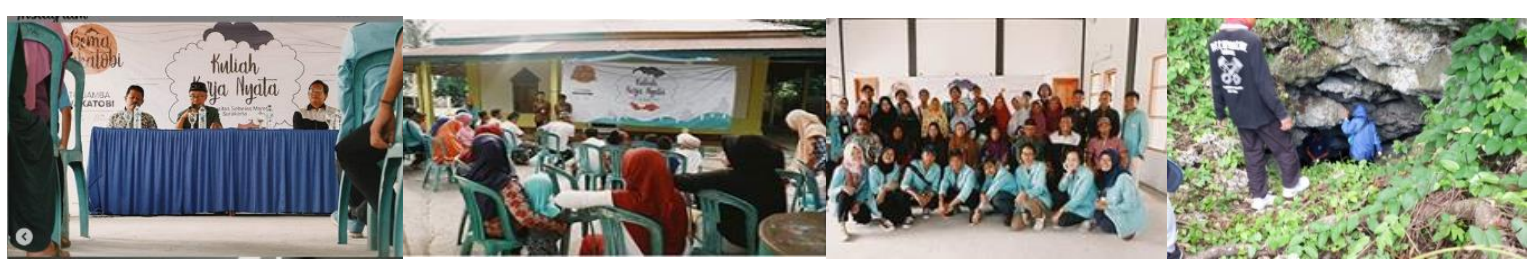

Gambar 3. Verikultur, Penyuluhan Pertanian, Survey Gua, Penyaringan dan Tadah Air Hujan

Latar belakang dilakukannya program kerja Survey Gua ini adalah melihat permasalahan mengenai kebutuhan air terutama di Desa Waginopo yang masih mengandalkan air PDAM yang hanya hidup dua hari selama seminggu. Kegiatan ini dimaksudkan untuk mendata gua-gua yang ada di Kecamatan Wangi-Wangi menggunakan sebuah form dan dapat digunakan sebagai arsip desa. Fungsi pendataan gua ini adalah untuk mengetahui potensi gua tersebut atau kemudian dapat dipublikasikan supaya menarik minat para penelusur gua untuk melakukan eksplorasi. Faktor pendukung dalam kegiatan ini adalah adanya perangkat desa serta warga desa yang menemani dalam melakukan eksplorasi menemukan gua-gua yang ada di area Kecamatan Wangi-Wangi. Selain itu antusiasme warga dan perangkat desa sangat mendukung untuk ditemukannya sumber mata air baru. Faktor penghambat dari pelaksanaan program kerja ini adalah masih kentalnya adat serta unsur kepercayaan yang dianut warga dalam memasuki daerah-daerah keramat menyebabkan sulit dilakukan pendataan, akibatnya potensi dari gua yang telah didata kurang maksimal. Selain itu masih terbatasnya kendaraan menyebabkan kurang fleksibel dalam urusan mobilitas.

Hasil yang dicapai dari pelaksanaan program kerja ini adalah didatanya 4 gua baru di Kecamatan Wangi-Wangi yang salah satunya sudah digunakan sebagai mata air di salah satu desa dan terdapat 1 gua yang sudah didata yaitu Gua Kontamale, gua ini sudah dimanfaatkan sebagai sumber mata air serta sebagai tempat wisata. Selanjutnya, memberikan edukasi mengenai pentingnya memiliki arsip pendataan gua kepada beberapa perangkat desa supaya dapat dipublikasikan agar menarik minat para penelusur gua untuk melakukan eksplorasi dan juga dapat digunakan untuk melakukan pembaharuan sistem karst disetiap gua yang sudah didata. Tindak lanjut yang akan dilakukan adalah memberikan laporan hasil pendataan gua kepada desa untuk dijadikan arsip. Selanjutnya hasil dari pendataan gua ini dapat dilakukan publikasi kepada kelompok-kelompok penelusur gua. Beberapa kegiatan tersebut di atas disampaikan di Gambar 3.

Waginopo Bersih Berseri merupakan kegiatan kerja bakti yang dilakukan bersama warga desa Waginopo. Kegiatan ini berupa kegiatan membersihkan Taman Puncak Toliamba yang berada di desa Waginopo. Hal ini didasari karena kurang terawatnya taman toliamba yang sekaligus merupakan tempat wisata yang memiliki view yang sangat indah dan menghadap ke laut. Harapan setelah dilakukannya program ini yaitu agar menumbuhkan kesadaran masyarakat desa Waginopo akan potensi besar yang dimiliki oleh tempat ini. Sehingga warga desa dapat merawat, menjaga dan mengoptimalkan tempat wisata ini agar dapat menjadi sumber pemasukan yang berkelanjutan untuk desa Waginopo. Keberjalanan program ini didukung oleh desa dan warga desa sehingga kolaborasi kerja bakti yang dilakukan oleh warga desa dan tim KKN dapat berjalan lancar. Namun karna minimnya anggaran sehingga kegiatan menanam tanam hias tidak dapat dilakukan. Meskipun demikian, hal ini dapat diatasi dengan menyusun konsep taman Toliamba yang diajukan ke Desa dan Dinas Pariwisata. Sehingga, dapat dianggarkan untuk tahun berikutnya. Hasil yang dicapai dari kegiatan ini adalah taman Toliamba menjadi lebih bersih dan kesadaran masyarakat akan oengembangan potensi wisata mulai tumbuh serta konsep taman Toliamba yang disusun dan dirancang tim KKN diharapkan dapat terwujud di tahun selanjutnya sehingga taman Toliamba dapat menjadi tempat wisata alternatif.

Workshop penyaringan air hujan ini dilaksanakan di Masjid Desa Waginopo dengan kegiatan menjelaskan alat penyaring air hujan yang sudah dibuat selama 3 hari sebelumnya. Workshop air dilakukan dengan 2 tahap yakni pembuatan alat dan sosialisasi. Alat penyaring air hujan diintegrasi dengan penampung air hujan yang selanjutnya ditampung dalam bak penampungan. Kegiatan ini dilakukan untuk memberi refrensi kepada warga tentang alternatif penanggulangan kekurangan masalah 
air bersih. Mengingat belum adanya sumber air bersih baik sumur, maupun mata air alam di Desa Waginopo, maka dilakukan kegiatan ini untuk dapat memanfaatkan sumber daya alam yang ada khususnya air hujan. Program kerja penyaringan air hujan dapat berjalan lancar karena adanya faktor pendukung yakni ketersediaan sumber air bersih yang minim, sehingga dapat menjadi salah satu alternatif penanggulangan masalah. Selain itu, warga sudah melakukan penampungan namun tanpa penyaringan sehingga hanya menambah perangkat saja. Sudah adanya bak penampung di lokasi pemasangan juga sangat mempermudah pembuatan alat. Faktor penghambat yang mempengaruhi program adalah peserta workshop yang tidak sesuai target karena awalnya target adalah bapak-bapak namun mayoritas yang datang adalah ibu-ibu.

Hasil yang dicapai dari pelaksanaan progran kerja ini adalah terealisasinya alat percontohan penyaringan air hujan yang dipasang di lingkungan Masjid sebagai alternatif penanggulangan masalah kekurangan air bersih. Tindak lanjut yang diharapkan adalah alat yang sudah dibuat dapat menjadi percontohan bagi warga untuk membuat di rumah masing-masing.

Desa Waginopo mempunyai masalah air yang cukup menyulitkan masyarakat. Desa Waginopo hanya mengandalkan air PDAM yang tersedia hanya 2 hari dalam seminggu. Pembangunan dan peranacangan tadah air hujan efektif dilakukan di Masjid Khanatul Ain desa Waginopo. Pembangunan dilakukan secara bertahap dan diaplikasikan. Sosialisasi pembuatan tadah air hujan dilakukan bersama warga sekitar desa di halaman depan masjid dengan mengamati instalasi tadah dan penyaringan air hujan. Dengan harapan dapat menjadi contoh yang dapat membantu masyarakat desa untuk membangun di rumahnya masing-masing. Kami berupaya membantu memenuhi kebutuhan air bersih untuk wudhu dan mandi cuci kakus khususnya saat musim hujan. Pembangunan tadah air hujan mengalami beberapa hambatan yang lebih teknis. Tempat menampung atau tandon sangat susah didapat di pulau Wangiwangi ini. Harga-harga material bahan bahan pembuatan di pulau Wangi-wangi juga lebih mahal dibanding harga di pulau Jawa. Sedangkan hambatan pada sosialisai adalah medan untuk pengamatan instalasi tadah air hujan yang cukup relatif susah karena elevasi yang tidak rata. Faktor yang mendukung pembangunan tadah air hujan adalah mudahnya mencari bambu untuk pembangunan tower penahan tandon penampung. Banyaknya bambu di desa Waginopo memudahkan pengambilan bambu secara gratis. Sedangkan untuk sosialisasi masyarakat sangat mendukung dengan memperhatikan dan aktif bertanya tentang tadah air hujan yang baik dan efektif.

Hasil yang dapat ditinggalkan adalah instalasi tadah air hujan di masjid Khanatul Ain untuk kebutuhan air wudhu dan mandi cuci kakus pada musim hujan. Tindak lanjut nya untuk tadah air hujan adalah perawatan secara berkala untuk daun daun yang gugur di atas tadah air hujan. Daun-daun gugur membuat air terhambat masuk ke tandon penampungan. Kurangnya partisipasi masyarakat untuk datang ke masjid. Harapan kami pada awalnya partisipasi banyak diikuti oleh bapak-bapak rumah tangga yang dapat membangun instalasi tadah air hujan di rumahnya masing-masing. Masyarakat yang datang pada sore hari mayoritas adalah ibu-ibu. Faktor mencari kerja dengan merantau ke pulau lain membuat peserta yang hadir adalah ibu-ibu rumah tangga. Awalnya kami ingin mengundang perwakilan dari PDAM untuk menjadi pembicara mengenai pemanfaatan air hujan. Namun karena berhalangan pada hari yang di tentukan, pembicara tidak dapat dihadirkan pada sosialisasi. Pembuatan poster untuk tutorial pembangunan tadah air hujan belum terlaksana dan tertempel di dekat instalasi. Belum dapat menghadirkan pembicara khusus untuk menangani asalah air secara berkelanjutan di desa Waginopo. Penyuluhan pertanian merupakan program kerja penunjang dari bidang lingkungan. Kegiatan ini dilaksanakan di Aula Serba Guna Desa Waginopo pada hari Sabtu, 8 Februari 2020. Kegiatan ini diikuti oleh 50 warga yang berasal dari Dusun Toliamba Jaya dan Dusun Waginopo. Peserta dari kegiatan banyak berasal dari masyarakat yang berkegiatan di sektor pertanian. kegiatan ini dilakukan dengan tujuan untuk menambah wawasan masyarakat mengenai inovasi pertanian dan memperkenalkan masyarakat dengan trend pertanian organik. Kegiatan penyuluhan pertanian ini dapat terlaksana dengan lancar berkat kerjasama yang baik antara mahasiswa KKN, perangkat desa, dan khusunya bersama masyrakat yang berkegiatan di sektor pertanian. Hambatan dalam pelaksanaan program penyuluhan pertanian ini ialah cuaca yang kurang mendukung keberlangsungan kegiatan. Meskipun kegiatan 
dilaksanakan di tempat tertutup, namun hujan yang turun dengan intensitas waktu yang cukup lama menyebabkan kemunduran waktu pelaksanaan kegiatan akibatnya peserta yang hadir diawal waktu sedikit. Beruntung kegiatan dapat terlaksana dengan lancar tanpa menemu kendala berarti meskipun terdapat kemunduran waktu pelaksanaan.

Hasil yang dicapai dari pelaksanaan kegiatan penyuluhan pertanian ini adalah bertambahnya wawasan masyarakat mengenai inovasi pertanian dan bertambahnya pengetahuan masyarakat mengenai praktik pertanian organik. Selain itu adanya wacana untuk penerapan pertanian organik di Desa Waginopo menjadi salah satu pencapaian dan dukungan dari perangkat desa serta dinas pertanian karena adanya kegiatan penyuluhan pertanian.

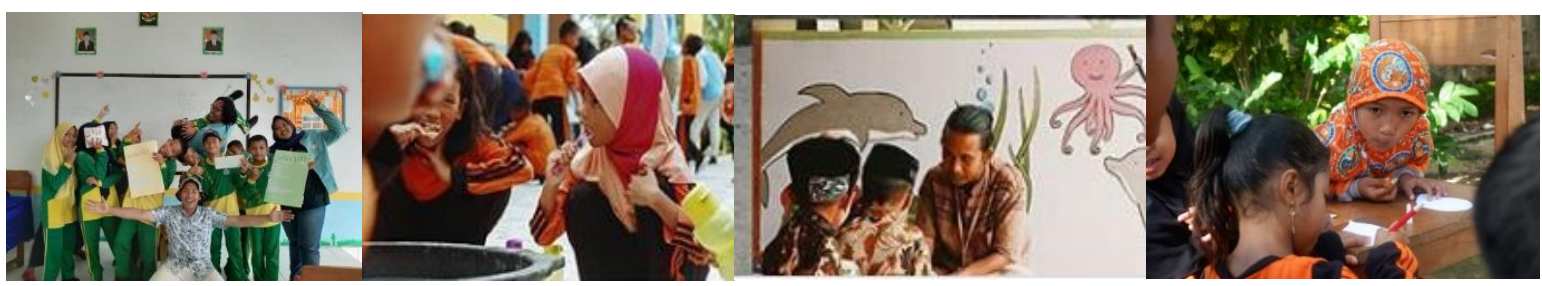

Gambar 4. Kegiatan Rumah Kreasi, Plural Is Me, Who am I, What Is Your Name

Kegiatan Penyuluhan PHBS dilaksanakan dalam beberapa rangkaian kegiatan. Kegiatan yang pertama yaitu senam bersama yang dilaksanakan di SMP Negeri 3 Wangi-wangi. Kegiatan selanjutnya yaitu senam bersama serta penyuluhan sikat gigi dan cuci tangan yang dilaksanakan di SD Negeri Waginopo. Kegiatan senam bersama dan penyuluhan sikat gigi dan cuci tangan dilakukan untuk meningkatkan kesadaran dan pengetahuan anak-anak generasi di desa Waginopo akan pentingnya perilaku hidup bersih dan sehat agar dapat menghindari serta mencegah tubuh dari berbagai macam penyakit. Selain senam bersama dan penyuluhan sikat gigi dan cuci tangan, kegiatan penyuluhan PHBS ini juga dilengkapi dengan Penyuluhan Demam Berdarah.

Penyuluhan demam berdarah ini dilaksanakan agar tidak hanya kalangan anak anak saja yang mendapatkan pengetahuan mengenai perilaku hidup bersih dan sehat, namun kalangan dewasa sebagai orang tua pun mengerti akan pentingkan perilaku hidup bersih dan sehat. Kegiatan penyuluhan demam berdarah ini dilaksanakan pada Selasa, 4 Februari 2020 di Aula Serbaguna Desa Waginopo. Kegiatan ini dilakukan karena banyaknya populasi nyamuk di Desa Waginopo. Populasi nyamuk yang banyak ini dikarenakan wilayah desa Waginopo yang berada di pegunungan dan banyaknya pepohonan di lingkungan desa. Selain lingkungan desa yang berada di pegunungan, banyaknya penampungan air di setiap rumah meningkatkan kemungkinan terjadinya perkembangbiakan nyamuk. Oleh karena itu, kegiatan ini dirasa penting untuk pencegahan penyebaran penyakit demam berdarah khusunya di desa Waginopo. Program kegiatan penyuluhan PHBS ini berjalan dengan lancar karena adanya kerjasama tim mahasiswa KKN dan pihak sekolah yang tekah memberikan fasilitas serta waktu dalam menjalankan kegiatan. Penyuluhan demam berdarah juga berjalan dengan lancer karena adanya kesediaan pihak Dinas Kesehatan Kabupaten Wakatobi untuk menyediakan pembicara sebagai pemateri pencegahan demam berdarah. Hambatan dari pelaksanakaan program kerja ini adalah terlambatnya berbagai macam pihak mulai dari sekolah, warga, maupun dinas yang membuat dimulainya acara menjadi mundur sehingga waktu yang dapat digunakan semakin terbatas. Namun hal tersebut tidak menjadi masalah yang sangat berarti karna antusiasme yang tinggi dari berbagai pihak tersebut menjadikan acara berjalan lebih menarik dan ramai. Hasil yang di capai dari pelaksanaan program ini disamapiakan di Gambar 4 adalah anak-anak mampu menggosok gigi dan mempraktekan gerakan cuci tangan dengan baik dan benar serta anak-anak mengerti kapan saja gosok gigi dan cuci tangan harus dilakukan. Selain itu, pengetahuan masyarakat mengenai pencegahan demam berdarah dengan cara 3M meningkat. 
Jurnal SEMAR Vol. 9 No. 1 , hal. $36-47$

ISSN: 2302-3937 | Copyright @ LPPM Universitas Sebelas Maret

Homepage: https://jurnal.uns.ac.id/jurnal-semar

\section{Kesimpulan dan Saran}

Serangkaian kegiatan selama KKN telah dilaksanakan dan dapat disimpulkan bahwa keberadaan KKN merupakan salah satu bentuk pengabdian kepada masyarakat yang masih sangat dibutuhkan oleh masyarakat. Antuasiasme masyarakat yang menginginkan masukan untuk pembangunan di desa Waginopo Wangiwangi Wakatobi Sulawesi Tenggara. Masyarakat sangat mendukung programprogram yang dibawakan. Berbagai masukan, pandangan dan harapan mereka sampaikan demi kemajuan desa. Di mana fokus yang diharapkan oleh masyarakat adalah terciptanya kemajuan desa. Namun perlu diperbaiki ke depan adalah data yang lebih konkret dari masyarakat baik sebelum dan sesudah dilaksanakannya KKN sehingga keberhasilan program KKN dapat lebih terukur, baik berbentuk kuesioner ataupun hasil wawancara. Serta alangkah lebih baik ada program yang berkelanjutan yang bisa dipaparkan dalam program KKN ini sehingga perkembangan keberhasilan program KKN dapat terukur setiap tahunnya pada peningkatan ekonomi masyarakat dan partisipasi masyarakat pada pembangunan.

\section{Ucapan Terima Kasih}

Kegiatan pengabdian masyarakat ini merupakan program KKN UNS yang dibiayai dengan dana PNBP UNS tahun 2020. Ucapan terimakasih disampaikan secara khusus kepada bapak "Thoriq" La Ode Rujunia selaku sekretaris desa Waginopo dan bapak La Ode Nasrianto selaku PLT Kepala Desa Maleko dan pengurus desa yang lain. Juga ucapan terima kasih kepada anggota tim KKN yaitu Caesar Alvian Ferdiansyah, Arifah Husna, Maula Afni Tamami, Judith Belinda Wijaya, Maria Regina Natasha Ika, Abdur Rahman Aziz, Abdan Syakura Muqaffi, Prabawati Kusuma Jati, Corry Prisilia, Kristophorus Satya Erlangga Yeriantoro, Julius Pandu Winata Manurung, Nur Muhammad Harahap, Muhammad Azhar Nugraha, Muhammad Saiful Islam, Husain Abiyyu, Ekty Nabilah, Mikhael Jason Abimanyu, Adhika Narendra Widyarsa, Muchammad Yusuf, Retno Aulia Zikri, semoga masa depan cerah selalu mengiringi anda sekalian.

\section{Referensi}

Fandeli, Chafid. (1995), Pengertian dan Kerangka Dasar Kepariwisataan dalam "Dasar-dasar manajemen Kepariwisataan Alam". Editor: Chafid Fandeli, Liberty, Yogyakarta

Febrianti Dwi Cahya Nurhadi, Mardiyono, dan Stefanus Pani Rengu. (2014). Strategi Pengembangan Pariwisata Oleh Pemerintah Daerah Terhadap Pendapatan Asli Daerah (Studi pada Dinas Pemuda, Olahraga, Kebudayaan dan Pariwisata Kabupaten Mojokero). Jurnal Administrasi Publik (JAP), Vol. 2, No. 2, 325-331

Joyosuharto, S. (2000). Aspek Ketersediaan dan Tuntutan Kebutuhan Dalam Pariwisata, dalam "DasarDasar Manajemen Kepariwisataan Alam, Editor: Ch. Fandeli, Liberty, Yogyakarta

Meiwany A. K. Tapatfeto dan Juita L.D Bessie. (2018). Srategi Pengembangan Objek Wisata Dalam Upaya Peningkatan Kunjungan (Studi Pada Objek Wisata Pantai Oetune Kabupaten TTS). Journal of Management (SME's), Vol. 6, No.1, 1-20

Pendit, Ny. S. (1990), Ilmu Pariwisata, Sebuah Pengatar Perdana. PT Pradnya Paramita, Jakarta

Sefira Ryalita Primadany, Mardiyono, dan Riyanto. (2013). Analisis Strategi Pengembangan Pariwisata Daerah (Studi pada Dinas Kebudayaan dan Pariwisata Daerah Kabupaten Nganjuk). Jurnal Administrasi Publik (JAP) Brawijaya, Vol. 1, No. 4, 135-143

Soebagyo. (2012). Strategi Pengembangan Pariwisata di Indonesia. Jurnal Liquidity, Vol. 1, No. 2, $153-158$

Spilane, JJ., (1987), Pariwisata Indonesia, Sejarah dan Prospeknya, Kanisius, Yogyakarta

Sunardhi W. (2018). Pembelajaran Mahasiswa KKN Terintegrasi PPM Universitas Padjadjaran Dalam Menyampaikan Prototipe Hasil Penelitian Program Academic Leadership Grant Kepada Masyarakat Pengguna dan Calon Pengguna, Jurnal Pengabdian kepada Masyarakat Unpad, Vol 2 No 9, 780-783

Syamsul Hadi, Dody Ariawan, Zainal Arifin, Muchlish, dan Alfian (2019). Pengembangan Desa Melalui Optimalisasi Literasi, Pariwisata, Kesehatan, dan Sosial di Kecamatan Riung, Ngada, NTT. Jurnal SEMAR Vol. 8 No. 2, 39 - 48 
Jurnal SEMAR Vol. 9 No. 1 , hal. $36-47$

ISSN: 2302-3937 | Copyright (C LPPM Universitas Sebelas Maret Homepage: https://jurnal.uns.ac.id/jurnal-semar

Universitas Sebelas Maret (UNS). (2013). Pedoman Penyelenggaraan Kuliah Kerja Nyata Universitas Sebelas Maret, SK Rektor 579/UN27/PP.2013 